\title{
A TYPIFICATION OF FOUNDRY PRACTICES FOR CORRECT ARTISANAL SAND CASTING OF ALUMINUM POTS
}

\author{
T.N. Guma, \\ Department of Mechanical Engineering \\ Nigerian Defence Academy, Kaduna, \\ Nigeria
}

\begin{abstract}
Artisanal green sand casting of aluminum pots is a flourishing business in Kaduna and some other metropolitan areas of west and central Africa. The business is however seen to be characterized by laborious and inconsistent control of many variables with defects in the castings and suboptimal productivity. The need for using correct foundry procedure for casting the pots is exemplified in this paper by casting a defect-free cylindrical flat-bottom 60-litre capacity pot of internal diameter $314.7 \mathrm{~mm}$ and depth $386 \mathrm{~mm}$, wall thickness $4 \mathrm{~mm}$ and mass $6.19 \mathrm{Kg}$ with its cover and handling lugs. The casting process involved design and production of the mold for the pot, local souring and melting and pouring of aluminum into the mold cavity, solidification monitoring, and removing and trimming the casting. The total cost of cast-producing the pot was about Ten Thousand Nigerian Naira $(\mathrm{N10}, 000)$ only compared to artisanal sand-cast pots of comparable size within Kaduna metropolis that cost well above this according to our study survey. To understand the quality of the pot, its chemical composition and simulated strength analyses were conducted. The analyses indicated a pot of sound quality on the basis of health-safe aluminum make and strength integrity. The work is intended to serve as foundry procedure that can be typically followed for any entrepreneurial or research interests for minimizing laboriousness and scraps, improving consistency and productivity, and maximizing profits in artisanal green sand pot casting business.
\end{abstract}

Key words: Casting variables, artisanal practices, subjective and inconsistent control, laboriousness, correct foundry practices, consistency, maximum business returns.

\section{INTRODUCTION}

Without cookware humans cannot easily cook their foods. Pots are used in almost all households, kitchens, and restaurants

\author{
Ogboi Lilian Uche \\ Department of Mechanical Engineering \\ Nigerian Defence Academy, Kaduna \\ Nigeria
}

to prepare our various meals. Aluminum pots are commonly used cookware because of their ability to heat and cool more quickly, light-weight and fair strength, excellent corrosion resistance, low cost due to availability of raw materials, ease to be fabricated and formed and machined, unsurpassable recyclability and casting properties of the raw materials, durability, etc, compared to most other food-grade metal containers Guma and Durami (2019).

Foundry technology is one of the vital bases for rapid industrial development of any nation. Sand casting is the most versatile, widely used and important method of casting and accounts to about $70 \%$ of all foundry products Guma (2010, 2012), Ogboi (2018), Guma and Ogboi (2019). These advantages alongside those of aluminum cookware could be the main reasons why artisanal green sand casting of pots using aluminum scraps is a flourishing business in Kaduna metropolis and some other urban areas in west and central Africa. Many people find gainful employment in the business and many more profitably trade with the pot castings. The major buyers and end users of the pots are people from homes and restaurants where firewood is customarily used for cooking. Most of the pot users prefer them because of their affordability at cheaper rate, and ability to be produced with fair quality in customized or traditional shapes of various sizes compared to the industryproduced types which are also available in the market for sale.

In Kaduna metropolis, aluminum pots are cast using unmodified green sand sourced in the vicinity of river Kaduna around Kaduna metropolis. People involved in the business include those who once worked in foundries where they experientially acquired their foundry knowledge, technical school leavers or trade centre trainees who learnt to some extent how to cast, and those who acquired their casting skills through apprenticeship in the business itself Guma (2010, 2012), Ogboi (2018), Guma and Ogboi (2019) . To successfully cast their pots, the workers use much labor and subjective skills to control a large number of process variables but often end up with some defective or scrap castings due possibly to incorrect factors in 


\section{International Journal of Engineering Applied Sciences and Technology, 2019 \\ Vol. 4, Issue 4, ISSN No. 2455-2143, Pages 169-178 \\ Published Online August 2019 in IJEAST (http://www.ijeast.com)}

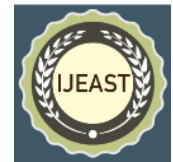

control such as: mix formulation of the molding sand, core size or materials used for it, design and make of the pattern, sand to casting weight ratio, quality of process tools and equipment used, melting and pouring conditions of the aluminum, design of the mold, ramming or compacting sand around the pattern, and solidification shrinkages of the casting Ogboi (2018), Guma and Ogboi (2019).

In foundries with research and development units, better control of such casting variables are understood through research efforts and more correct casting conditions are achieved to produce more consistent and better qualities with less labor Pandey (2015), Shuaib-Babata (2017), Suraiya Jabeen et al (2016). However, in artisanal pot casting business which is mostly carried out at shop level, majority of the workers involved in the casting business are seen to lack proper foundry knowledge and control of the sand and its usage as well as other practices to achieve consistency and optimal productivity with better business returns Guma (2010, 2012), Ogboi (2018), Guma and Ogboi (2019). Survey of artisanal practices in sand casting of pots in Kaduna metropolis as part of this research Ogboi (2018), showed specifically that:

i. Unlike practices in standard foundries, the workers do not have laboratories or test their sands and other molding materials to know whether satisfactory levels are achieved or not Pandey (2015), Shuaib-Babata (2017).

ii. The workers use and mix aluminum scraps from different sources but do not analyze the chemical composition of their pot makes to know whether the makes conform to safety requirements for aluminum as a food grade material or not. This is because pure aluminum and some grades of aluminum alloys are not acceptable as food grade metals according to many reputable national and international authorities such as WHO and Food and Drug Administration (FDA) since aluminum can contain health-risky quantity of some elements which can leach into food whose frequent intake into the human body system can cause diseases such as liver toxicity and lead to degenerative symptoms, including Alzheimer's disease Suraiya et al (2016), Salas et al (2012), Technical Document Guidelines (2002).

iii. The workers' casting designs and productions are subjective and based on experience so consistencies and qualities of their product types cannot be ensured.

iv. The molding materials, methods and tools used by the workers can be inferior by engineering standards.

v. Many people from the public may desire to know for entrepreneurial or research interests, the details and problems involved in the artisanal casting processes but such information is hardly available Guma (2010, 2012).

The surveys also showed that visually, most of the cast pots looked good but many do end up as scraps or with defects during the casting process. For example, Fig. I shows a pile of some of the surveyed pots that were visually defects-free pots and, Fig. 2 a defective pot Ogboi (2018).

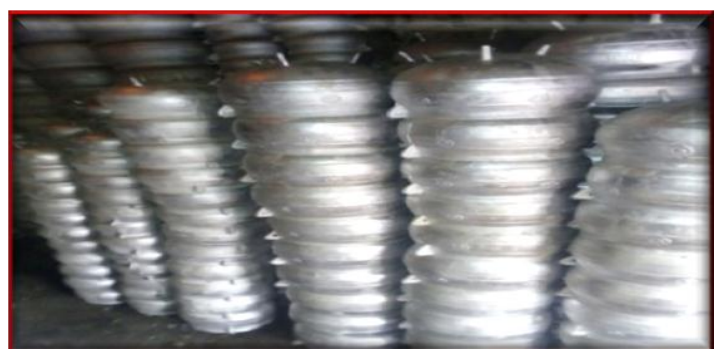

Fig. 1: A pile of visually defects-free pot castings in a foundry shop at Panteka Tudunwada in Kaduna metropolis

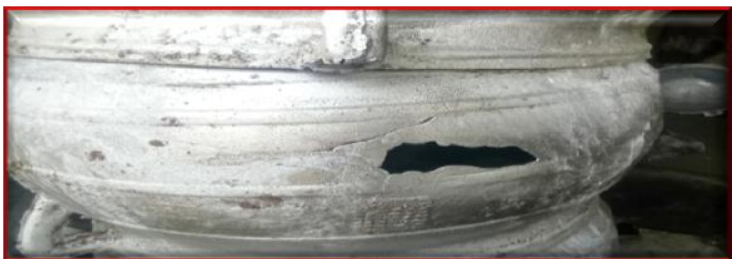

Fig. 2: A pot casting with defect

Such scraps or defective castings are often recycled a number of times before satisfactory pots are cast from them.

\section{A. Aim and Objectives}

The aim of the paper is to present correct foundry procedure for casting a 30-Litre capacity aluminum pot alongside with its component parts using scrap aluminum, green sand sourced from banks of river Kaduna, and facilities that are usually used for artisanal green sand casting of aluminum pots in Kaduna metropolis to exemplify the principles that can be followed for improvement in the pot casting business. The objectives are: Ogboi (2018).

i. To recognize the much contribution artisanal pot casting Business Avenue has been making to selfemployment and economic development in Kaduna metropolis and Nigeria in general by supplying pots needed and used in the city and other parts of the country and even beyond.

ii. To complement the contribution by emphasizing and exemplifying the use of correct foundry concepts for improving consistency and productivity, minimizing scraps and labor, and maximizing profits in the business. 


\section{International Journal of Engineering Applied Sciences and Technology, 2019 Vol. 4, Issue 4, ISSN No. 2455-2143, Pages 169-178 \\ Published Online August 2019 in IJEAST (http://www.ijeast.com)}

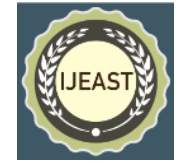

iii. To contribute in providing basic information that some people may want to know for enterprising in the pot casting business or positive research purposes.

\section{METHODOLOGY}

\section{A. Sourcing of Raw Materials}

The raw material used for casting the pot was sourced from scrap aluminum items in Kaduna metropolis in line with the practice used by artisans for casting their pots. Care was however taken by observation and experience and discussion with the suppliers to ensure that only items that had been used in contact with food were acquired instead of any aluminum scraps which could include those from electrical machineries and transmission lines, pure aluminum, automobile and aircraft parts, window frames, furniture parts, etc that could not be food grade aluminum. The scraps sourced were those of industrial food processing facilities, cookware and other food containers from homes, restaurants and hotels. The scraps were bought wherever they were found available for sale, or directly obtained from some homes and restaurants or hotels as gifts. Altogether, about $40 \mathrm{Kg}$ of aluminum scraps were acquired at a cost of about six Thousand Nigerian Naira (N6, 000.00) for the study Ogboi (2018)

\section{B. Design of the Pot-Casting Mold}

A green sand mold with a tapered sprue, un-pressurized gating system ratio of $1: 3: 3$, and an open riser for compensating cavity shrinkages of molten aluminum during solidification which had previously been designed in accordance to engineering theoretical practicalities and reported by Guma and Ogboi (2019) for casting the 30-litre-capacity cylindrical aluminum pot alongside its cover and three semi-circular handling lugs was used. The design specified the requisite ladle position, sprue and well sizes, runner and in-gates dimensions, pattern make and dimensions, total mass and in-sprue flow rate and pouring time and cost of aluminum as well as molding box for optimally producing the pot castings Ogboi (2018), Guma and Ogboi (2019)

\section{Production of the Pattern for Molding}

The main pot pattern was produced according to its designed make and dimensions by Ogboi (2018), Guma and Ogboi (2019) using a wood lathe to turn a cylindrical dry mahogany wood of diameter $340 \mathrm{~mm}$ and length $396.244 \mathrm{~mm}$ to a diameter of $322.83 \mathrm{~mm}$ followed by drilling and boring it axially at one end to the correct hollow diameter of $31.47 \mathrm{~mm}$ and length $392.18 \mathrm{~mm}$. The pot cover pattern was also produced using the lathe by turning down another dry mahogany wood of length $300 \mathrm{~mm}$ and diameter $340 \mathrm{~mm}$ to a diameter of $319.7 \mathrm{~mm}$, then drilling and boring it at one end to a depth of $335.935 \mathrm{~mm}$ and diameter $307.7 \mathrm{~mm}$ and cutting it into two parts along its diameter at a distance of $285.778 \mathrm{~mm}$ from its open end and using the shorter of the two parts as the pot cover pattern. The handling lugs were produced by marking out the size and shape of the lugs on three cut-out suitably sized pieces from the wood and cutting out of the pieces into shape and polishing them to exact dimensions using various hand tools. The mahogany wood was bought in Kaduna at a cost of N2000.00. N1500.00 was paid to wood machinist to produce the three patterns. Thereto, the handling lug patterns were carefully placed and nailed at their designed locations on the main pot and cover patterns using small nails and a hammer Ogboi (2018), Guma and Ogboi (2019)

\section{Molding box}

A molding box of overall size $650 \mathrm{~mm}$ by $650 \mathrm{~mm}$ by $650 \mathrm{~mm}$ internal capacity was constructed of dry mahogany wood of $50 \mathrm{~mm}$ by $50 \mathrm{~mm}$ solid sectional thickness according to its design according by Ogboi (2018), Guma and Ogboi (2019) using carpentry tools.

\section{E. Sourcing Green sand}

The sand for molding was harvested from the banks of river Kaduna which passes through Kaduna metropolis in accordance to sourcing and test information provided on its foundry properties by Guma (2012). The sand was collected at some different locations up to depths of about two meters within bank strip width of about $200 \mathrm{~m}$ in close vicinity to Kaduna metropolis covering a distance of $8 \mathrm{Km}$ up and down the course of the river starting from a point on the river near the centre of the metropolis. Some artisans at the main pot casting business area in Kaduna metropolis located at Panteka Tudunwada who regularly used the river sand for casting were remunerated with Five Hundred Naira (N500.00) only for harvesting the sand. The harvested sand was conveyed in thick leather bags on a motor bike to site at Panteka Tudunwada for the study Ogboi (2018).

\section{F. Formulation of the Sand Mix for Molding}

The harvested sand from the different locations was thoroughly mixed with a molder's shovel in a foundry shop at Panteka Tudunwada to obtain a representative sand sample from the river basin. From the pot casting weight of $6.19 \mathrm{Kg}$ [5], a bowl and weighing scale were used to determine $40 \mathrm{Kg}$ of the representative sand sample in accordance with the required weight of 6.3 parts sand to one part aluminum casting for molding according to Alteams (2018). This was achieved by ensuring that the difference between the weight of the basin with and without sand in it was $40 \mathrm{Kg}$. 


\section{International Journal of Engineering Applied Sciences and Technology, 2019 \\ Vol. 4, Issue 4, ISSN No. 2455-2143, Pages 169-178 \\ Published Online August 2019 in IJEAST (http://www.ijeast.com)}

Instead of using the sand unmodified as it is customary done by the artisans, the $40 \mathrm{Kg}$ sand was mixed with Illo clay: a

locally obtainable clay in Kaduna metropolis to increase strength of the sand and water to account for any loss in moisture of the sand from the time it was harvested. The mixture was prepared with an attested optimal weight contents of $90 \%$ sand, $5 \%$ clay, and 5\% water for aluminum castings Guma (2012), Ogboi (2018), Sumaiya et al (2017).

\section{G. Mold Making}

The mold for casting the pot and its accessories was produced with the fabricated molding box and pattern using the prepared sands and various molding tools. The pattern, sprue with pouring basin and sprue well, and riser were first placed in position in the drag according to design of the molding box and the cope fitted accurately in matching position and clamping screws tightened. A hand shovel was used to pack the formulated sand and fill the molding box. A No.4 riddle was used for sifting the sand over the surfaces of the pattern. An iron rammer of about $0.8 \mathrm{Kg}$-mass with a flat face and wooden handle was used for tamping the sand around the pattern in the molding box. After ramming the sand to the brim of the cope, a sturdy steel strike was used to scrape the extra sand from the top of the cope and drag. Gate cutter made of brass bent to a semicircle on one edge was used to cut the in-gate. Tapered sprue cutters made to specification were used to produce the sprue by pressing it down from the cope side before stripping the mold from the pattern. Calipers were used to verify the sizes of sand cores Ogboi (2018) used to make the pot and its cover cavities in order to ensure their proper fits in the pattern. Fig. 3 shows the designed mold; while Plates Ia, Ib, and Ic show some instances of the molding process Ogboi (2018).

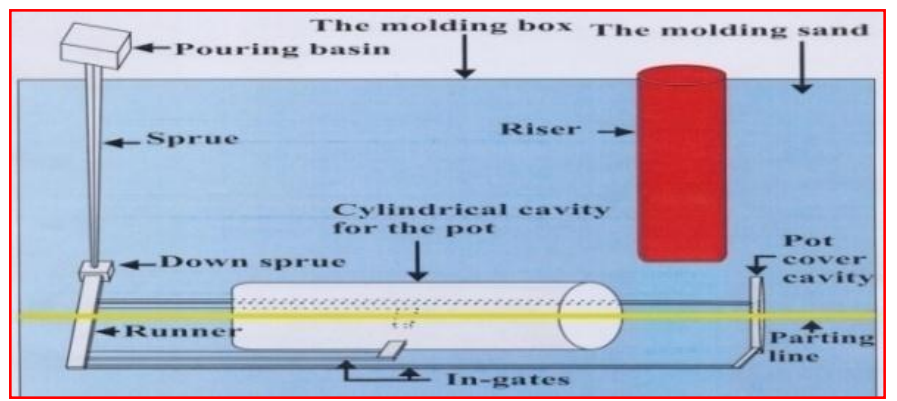

Fig. 3: A schematic of the produced mold Ogboi (2018), Guma and Ogboi ((2019)

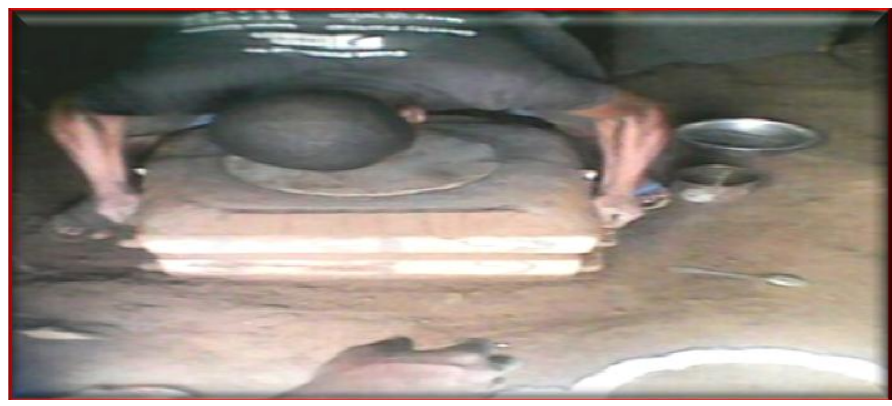

Plate Ia

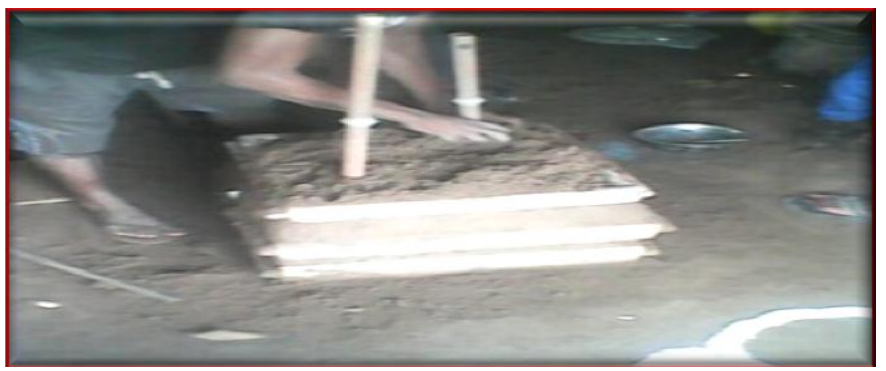

Plate $\mathrm{Ib}$

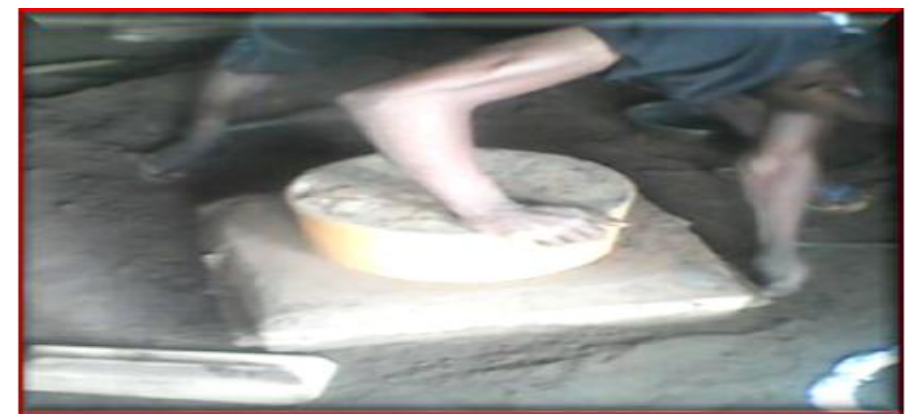

Plate Ic

Plate I (a, b, c): Instances of the molding process Ogboi (2018)

\section{H. Melting of Aluminum and Casting the Pot}

A usually employed charcoal fired pit furnace at Panteka Tudunwada for artisanal casting of pots was used to melt the procured aluminum scraps for the pot castings. About $7.46 \mathrm{Kg}$ of aluminum scraps, a little more than the $6.19 \mathrm{Kg}$ mass of aluminum required to cast the pot was weight-determined using a digital weighing scale. The scraps were melted by heating them to the melting point of aluminum at $660^{\circ} \mathrm{C}$ Ogboi (2018), Datau et al (2012) for sufficient time to ensure by visual observation that they were all properly melted. Before then, the surface of the produced mold cavity was lubricated with grease to facilitate removal of the castings afterwards, cores were positioned, and the mold halves closed and securely clamped 


\section{International Journal of Engineering Applied Sciences and Technology, 2019 \\ Vol. 4, Issue 4, ISSN No. 2455-2143, Pages 169-178 \\ Published Online August 2019 in IJEAST (http://www.ijeast.com)}

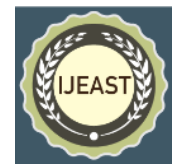

together to prevent loss of any aluminum melt and air entry. The molten aluminum was then ladled from its holding container in the furnace and poured at the melt temperature into the mold cavity at the sprue top Ogboi (2018), Datau et al (2012). After about 20 minutes after the solidification time of the castings, the mold was opened by gently breaking it with an iron rod to remove the casting. The removed pot casting was assessed for any visible defects. It was thence trimmed using a hack saw and files, and cleaned with coarse and then fine emery abrasive clothe to smoothen its surface. Plates II show some of the procured scrap aluminum products used and molten aluminum in a container in the pit furnace. Fig 3 shows the principal parts of the designed mold, and Plate III a side view of the cast pot. The total cost of casting the pot from the design stage, sourcing of materials, mold-making, melting scraps, casting and cleaning its surface was ten Thousand Naira (N10, 000) [4].

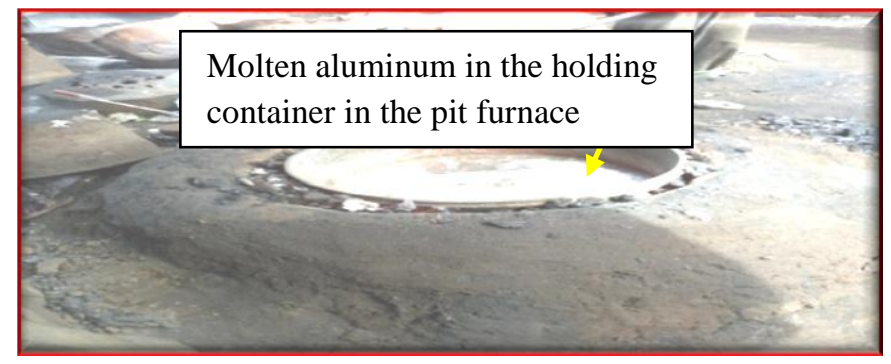

Plate II: The melting process showing scraps and molten aluminum in the melting container Ogboi, 2018

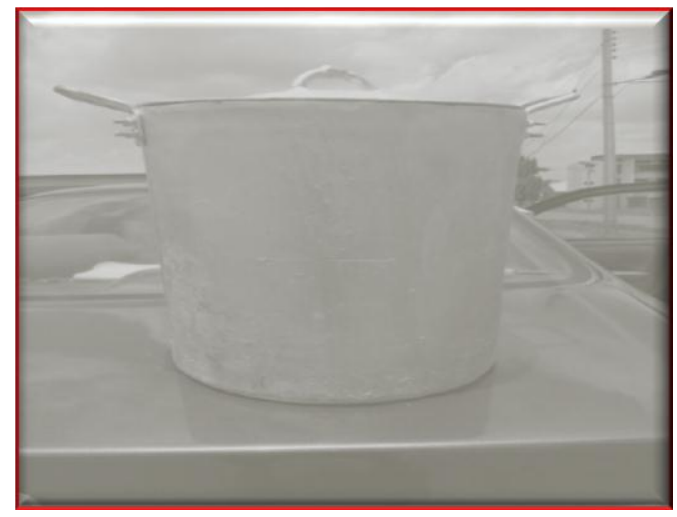

III: Side view of the cast pot Ogboi (2019)

\section{Chemical Composition Analysis of the Pot}

The chemical composition of the pot was analyzed at National Geological Survey Laboratories Barnawa, Kaduna, by the energy dispersive X-ray fluorescence analysis using Minipal 4 facility manufactured by Pan-analytical Limited Netherlands in accordance with the facility's manual and powders produced from molten aluminum used to produce the pot to assess its acceptability level as a food-handling aluminum container. Plate $\mathrm{V}$ shows a side view of the Minipal 4 facility used [4].

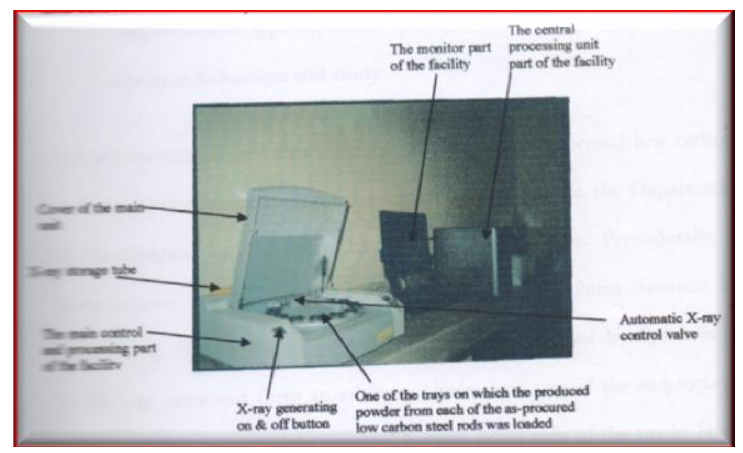

Plate V: A side view of the facility

\section{J. Strength Assessment of the Pot}

In order to understand the strength level of the cast pot as a critical parameter for assessing its quality, 40 ASTM E8 M11 tensile and 40 ASTM E23 impact test samples were machined from separately cast $16 \mathrm{~mm}$-diameter aluminum rods. The rods were cast using the same molten aluminum used to cast the pot and molds made with the same Kaduna river sand formulation used to cast the pot. The mold cavities for casting the samples were made with steel patterns machined to sizes of the ASTM samples with requisite allowances used by Guma and Ogboi (2019). The samples were machined in pairs on a lathe with each pair from one rod with the understanding that their average strengths would reasonably indicate the actual strength of the pot casting. Schematics of dimensional specifications of the ASTM standard test samples are shown in Figs. 4 and 5 while some of the cast rods are shown in Plate VI and some machined samples from the rods in Plates VII and VIII.

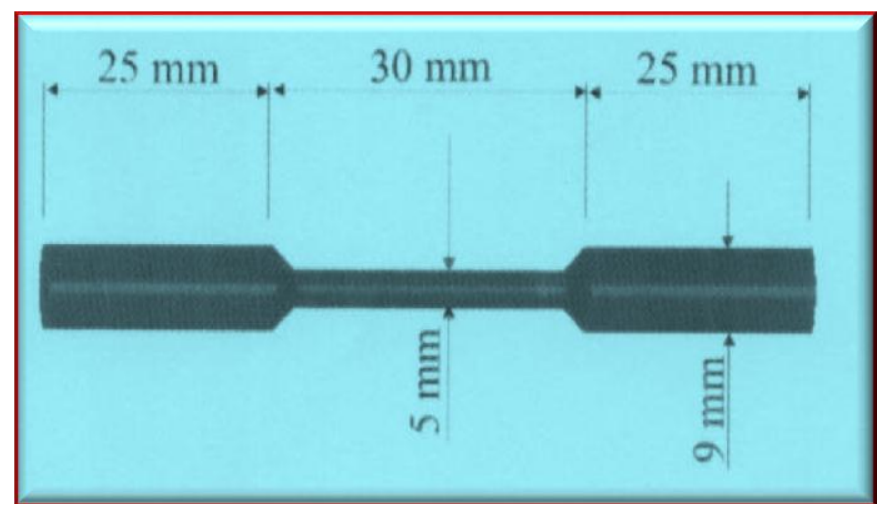


Fig. 4: The ASTM E8 tensile test sample

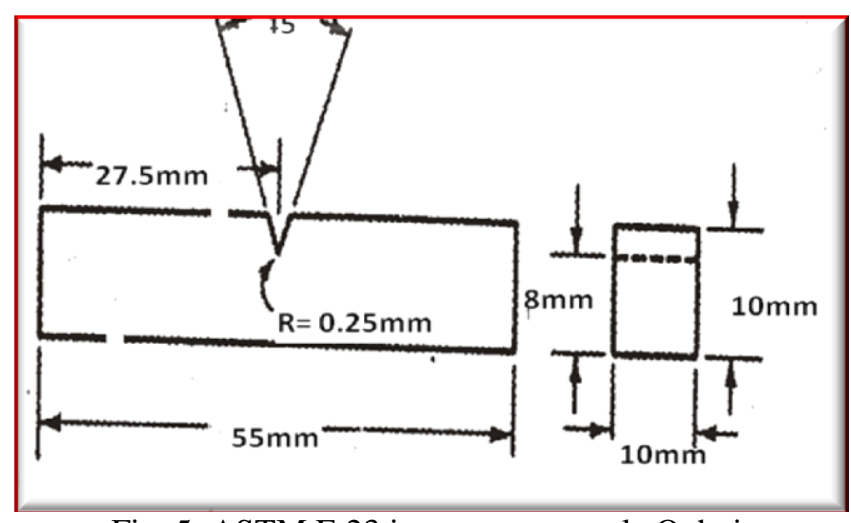

Fig. 5: ASTM E 23 impact test sample Ogboi

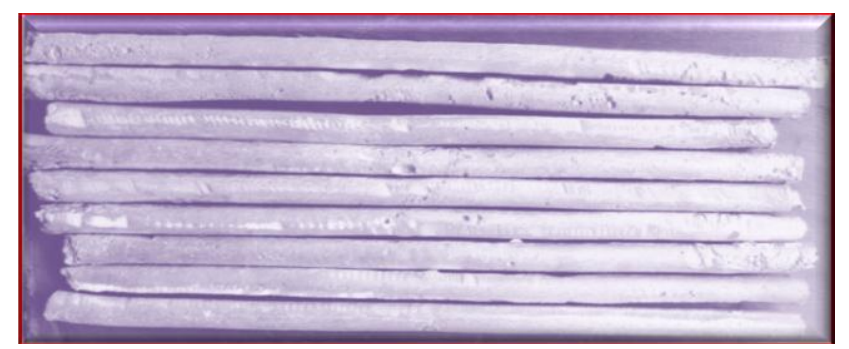

Plate VI: Some of the sand-cast aluminum rods

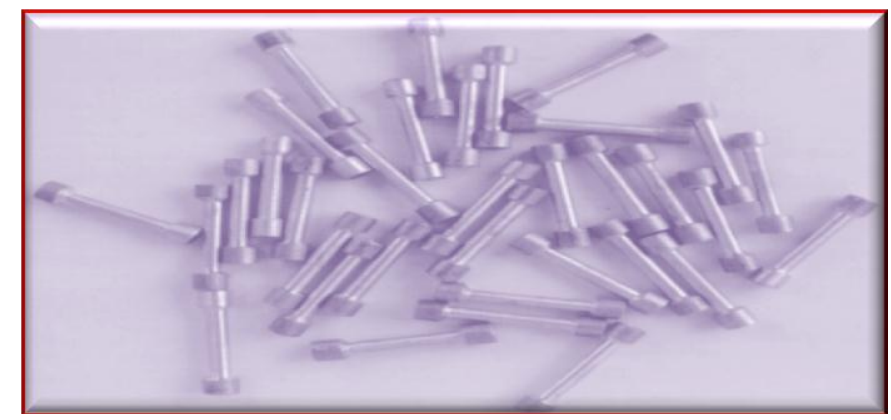

Plate VII: Some of the produced tensile test samples

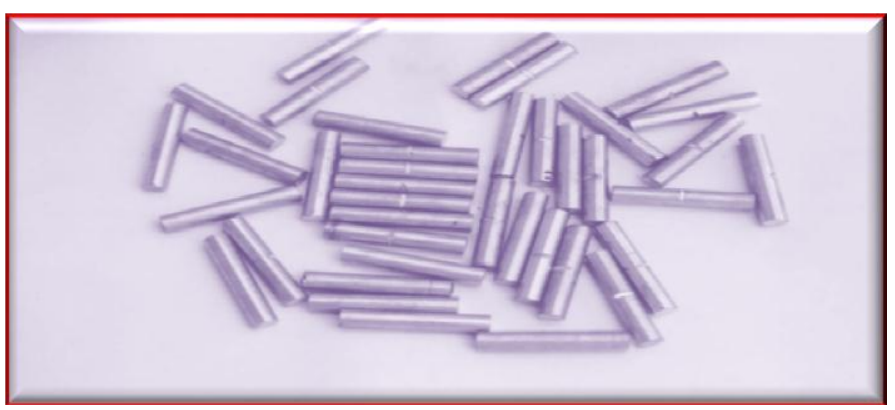

Plate VIII: Some of the produced impact test samples

\section{Tensile test}

The samples were tested of their fracture strengths by tensile loading at room temperature using using the Hounsefied tensometer manufactured by Tensometer Limited, England. Each sample was held in the sample-gripping jaws of the tensometer and subjected to gradually increasing applied loads until fracture occurred. The load and extension were recorded automatically by the tensometer on special graph paper. The plots on the graph paper were used to obtain the ultimate tensile loads and the loads converted to stresses by dividing each load by the initial cross sectional area the samples. The results were reported as the respective average pair values of the as-produced samples. Plate IX shows the process of loading a sample for test on the tensometer.

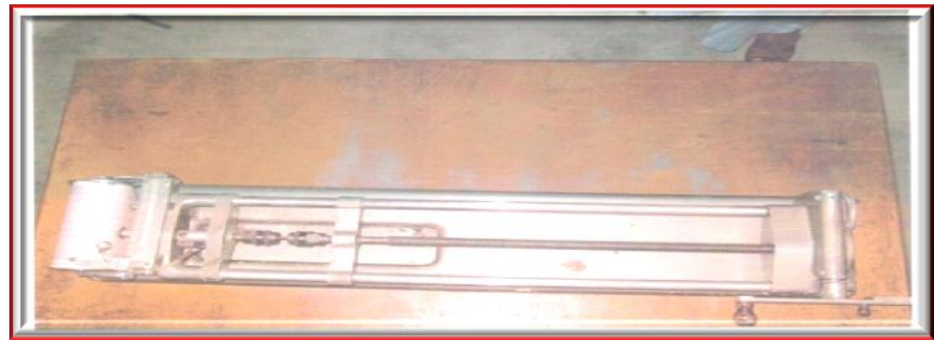

Plate IX: The tensometer used for the tensile test

\section{Impact test}

Impact test of the prepared samples were determined in accordance with the ASM procedure [14] using the Hounsfield balanced impact testing apparatus used for measuring impact strength. Each sample was appropriately held in the vice of the apparatus so that it was just a simple beam supported at the ends as shown in Plate $\mathrm{X}$. The sample was struck behind the V-notch by two released pendulums each of mass $2.443 \mathrm{~kg}$ travelling at a standard speed of $5 \mathrm{~m} / \mathrm{s}$ with a kinetic energy of 149.2 Joules in opposite directions from their calibrated height to fracture the sample. The energy remaining after fracture was determined in each case from the height rise of each pendulum and its weight. 


\section{International Journal of Engineering Applied Sciences and Technology, 2019 \\ Vol. 4, Issue 4, ISSN No. 2455-2143, Pages 169-178 \\ Published Online August 2019 in IJEAST (http://www.ijeast.com)}

The difference between the energy input and energy remaining represented the energy absorbed by the sample. In that way data was collected from the tests in sample pairs and reported as the respective average pair values.

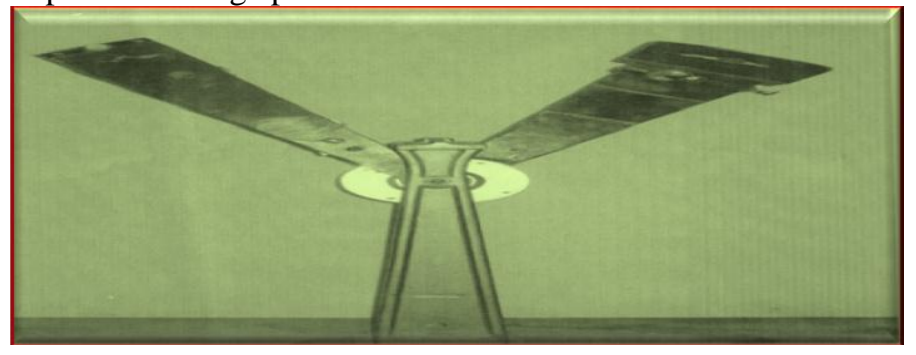

Plate X: The Hounsfield pparatus used

\section{RESULTS AND DISCUSSIONS}

\section{A. Results}

Results of the test analysis of the pot are presented as follows:

\section{Chemical composition of the pot}

The average percentage [\%] elemental weight chemical composition of the pot make is presented in Table 1.

Table 1: Chemical composition of the pot make Ogboi (2018)

\begin{tabular}{|l|l|l|l|l|l|l|l|l|}
\hline Element & $\mathrm{Ni}$ & $\mathrm{Si}$ & $\mathrm{Fe}$ & $\mathrm{Mg}$ & $\mathrm{Ti}$ & $\mathrm{Cr}$ & $\mathrm{Cu}$ & $\mathrm{Al}$ \\
\hline Composition [\%] & 0.098 & 2.317 & 1.495 & 5.161 & 0.088 & 0.165 & 0.027 & Balance \\
\hline
\end{tabular}

\section{Strength of the pot}

Results of tensile and impact tests the sample pairs with their average (Avg.), standard deviation (STDV) and range (R) values in each case as a simulated measure of strength of the cast pot are presented in Tables 2 and 3 respectively.

Table 2: Tensile strengths of the ASTM tensile samples in pair averages Ogboi (2018)

\begin{tabular}{|c|c|c|c|c|c|c|c|c|c|c|}
\hline Pair No. & 1 & 2 & 3 & 4 & 5 & 6 & 7 & 8 & 9 & 10 \\
\hline $\begin{array}{l}\text { Strength } \\
\text { [MPa] }\end{array}$ & 166.1 & 155.8 & 170.3 & 165.9 & 160.8 & 163.2 & 151.9 & 167.4 & 156.3 & 159.6 \\
\hline Pair No. & 11 & 12 & 13 & 14 & 15 & 16 & 17 & 18 & 19 & 20 \\
\hline $\begin{array}{l}\text { Strength } \\
\text { [MPa] }\end{array}$ & 161.8 & 157.5 & 154.7 & 166.6 & 167.2 & 164.8 & 158.7 & 169.3 & 155.6 & 150.2 \\
\hline
\end{tabular}

Average for the 20 sample pairs $=161.185 \mathrm{~N} / \mathrm{mm}^{2}$

Sample standard deviation for the 20 sample pairs $=5.948753 \mathrm{~N} / \mathrm{mm}^{2}$

Range for the 20 sample pairs $=20.1 \mathrm{~N} / \mathrm{mm}^{2}$

Table 3: Impact resistances of the ASTM impact samples in average pairs Ogboi (2018)

\begin{tabular}{|c|c|c|c|c|c|c|c|c|c|c|}
\hline Specimen pair No. & 1 & 2 & 3 & 4 & 5 & 6 & 7 & 8 & 9 & 10 \\
\hline Impact resistance[Joules] & 1.78 & 2.12 & 1.95 & 2.51 & 2.06 & 2.63 & 2.54 & 2.39 & 1.87 & 2.46 \\
\hline Specimen pair No. & 11 & 12 & 13 & 14 & 15 & 16 & 17 & 18 & 19 & 20 \\
\hline Impact resistance[Joules] & 2.24 & 1.81 & 2.53 & 1.66 & 1.59 & 1.84 & 1.78 & 1.98 & 1.63 & 2.25 \\
\hline
\end{tabular}

Average for the 20 sample pairs $=2.081$ Joules

Sample standard deviation for the 20 sample pairs $=0.3402$ Joules

Range for the 20 sample pairs $=1.04$ Joules

\section{B. Discussion}

\section{Chemical analysis}

Aluminum alloys can contain elements in quantities that negate health safety so when aluminum is used in the food industry, there are rules as to what the content of each aluminum alloy must be for food industry applications. There are maximum tolerances laid down according to European food law EN 602 (2007) in connection with use of aluminum in the food 


\section{International Journal of Engineering Applied Sciences and Technology, 2019 \\ Vol. 4, Issue 4, ISSN No. 2455-2143, Pages 169-178 \\ Published Online August 2019 in IJEAST (http://www.ijeast.com)}

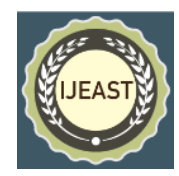

industry. The maximum content of certain elements in aluminum alloys used in the food industry are shown in Table 4 Technical Document Guidelines (2002), Foods Standard Agency Guidance (2008). From this and the results presented in Table 1, it is evident as can be observed that all the critical chemical elements in the aluminum used to cast the pot fall within the allowable composition for food grade aluminum.

Table 4: The maximum allowable content of certain elements in aluminum alloys used in the food industry Ogboi (2018), Technical Document Guidelines (2002), Foods Standard Agency Guidance (2008)

\begin{tabular}{|cccccccccccc|} 
Element & Si & Fe & $\mathbf{C u}$ & $\mathbf{M n}$ & $\mathbf{M g}$ & $\mathbf{C r}$ & $\mathbf{N i}$ & $\mathbf{Z n}$ & $\mathbf{Z i}$ & $\mathbf{T i}$ & Others \\
\hline $\begin{array}{l}\text { Max. content } \\
\text { by mass [\%] }\end{array}$ & 13.5 & 2 & 0.6 & 4 & 11 & 0.35 & 3 & 0.25 & 0.3 & 0.3 & 0.15 \\
\hline
\end{tabular}

From Table 2, it can be seen that the tensile fracture strengths of the casted tensile samples varied from 150.2 to $170.3 \mathrm{MPa}$ with average of $161.185 \mathrm{MPa}$, standard deviation of $5.948753 \mathrm{MPa}$, and a narrow range of $20.1 \mathrm{MPa}$.

According to European standards on foundry aluminum alloys (EN 1676 and EN 1706) the ultimate tensile strength (UTS) of the High Pressure Die Cast (HPDC) aluminum alloys is $240 \mathrm{MPa}$, and around $170 \mathrm{MPa}$ for the main Gravity Die Cast (GDC) alloys Anilchandra et al (2017). Also; the peak tensile strengths of reportedly cast Al 6063 alloy by Ayoola et al (2012) from three different sand molds made with $95.20 \%$ silica sand and sodium silicate $\left(\mathrm{NaSiO}_{3}\right)$ and negligible $\mathrm{CO}_{2}$ gas mixture, $86.95 \%$ silica sand and $8.7 \%$ Portland cement and $4.35 \%$ tempering water mixture, and $92.59 \%$ naturally bonded sand and $7.41 \%$ tempering water mixture were 125,118 , and $130 \mathrm{MPa}$ respectively. The ultimate tensile strengths of aluminum casting alloys (A356) obtained without and with addition of $0.1-0.2 \%$ Wt of Zn Onanorod by Qasim et al (2017) varied from 183.4 to 219MPa. The UTS of as-cast Al 6063 by Joseph et al (2018) using sand and metal molds were 146.7 and $163.5 \mathrm{MPa}$ respectively.The tensile strength of $\mathrm{Al}$ (2024) reportedly separately reinforced with 1 to $5 \%$ molybdenum disulphide $\left(\mathrm{MOS}_{2}\right.$ ) by Bhargavi and Ramanaiah (2014) ranged from 191.38 to $261.03 \mathrm{MPa}$.

The tensile strengths of most aluminum alloys vary from 124 to $290 \mathrm{MPa}$ at room temperature Aluminum Standards and Data 2006, ASM Handbook (2000).

From the foregoing, it is clear that the average tensile strength of $161.185 \mathrm{MPa}$ for the produced and tested aluminum samples have good comparability with what is obtainable from some aluminum castings. The differences can however be due to abilities of HPDC and GDC and some of the other methods of castings to produce better quality castings than sand castings and variation in the methods of sample preparation and testing and

\section{Strength analysis}

grades of the aluminum used. However, the average tensile strength of $161.185 \mathrm{MPa}$ of the sand-cast and tested samples in this work is seen to be high by comparison with all those values. This gives an indication that the produced pot was of satisfactory tensile strength.

From Table 3, it can be observed that the impact strengths of the test samples varied from $1.59 \mathrm{~J}$ to $2.63 \mathrm{~J}$ with a range of $1.04 \mathrm{~J}$, average of $2.081 \mathrm{~J}$ and standard deviation of 3.402J. According to studies by Shivkumar et al (1994), the impact strength of sand-cast aluminum alloy A356 at room temperature ranges from 1.1 to $7.3 \mathrm{~J}$. From this, it is indicative that the impact strengths of the test cast-produced ASTM samples were comparable with some other cast aluminum. It is therefore also understandable that the produced pot was of satisfactory impact strength.

\section{CONCLUSION, RECOMMENDATIONS AND ACKNOWLEDGEMENT}

\section{A. Conclusion}

Artisanal green sand casting of aluminum pots has being greatly contributing to small and medium scale entrepreneurial energies of many west and central African communities for some decades. The casting business is however seen to be characterized with laborious control of many production process variables and uncertainty of clear engineering practices that can raise doubts on the qualities of the castings and reduce confidence of some people in buying them. Optimal results cannot be achieved in any casting practice without proper engineering research inputs to minimize scraps or defects in the products by optimizing control of the many involved process variables such as mix formulation of the molding sand, core size or materials used for it, design and make of the pattern, sand to casting weight ratio, quality of process tools and equipment 


\section{International Journal of Engineering Applied Sciences and Technology, 2019 Vol. 4, Issue 4, ISSN No. 2455-2143, Pages 169-178 \\ Published Online August 2019 in IJEAST (http://www.ijeast.com)}

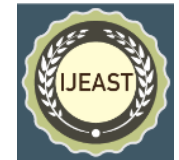

used, sourcing and melting and pouring conditions of the metal, mold design, ramming or compacting sand around the pattern, solidification shrinkages of the casting, quality control, etc. In this paper, sand casting and testing of a 30-litre capacity aluminium pot using locally sourced materials in Kaduna metropolis alongside control of other process variables in accordance with engineering principles has been presented. Analysis of chemical composition of the pot make and its simulated strength tests indicated that it was of sound quality. Also, cost analysis of the pot indicated that it was cheaper compared to pots of comparative volume capacities produced by foundry artisans in Kaduna metropolis. The research information is presented to serve as foundry procedure that can be typically followed for minimizing laboriousness and scraps, improving consistency and productivity, and maximizing profits in artisanal green sand pot casting business or for positive research interests.

\section{B. Recommendations}

The following recommendations are made from the work:

i. The work should serve as procedural engineering principles to be followed for improving consistency and productivity, minimizing scraps, and maximizing profits in artisanal green sand casting of any desired sizes and shapes of aluminum pots especially in Kaduna metropolitan area.

ii. The work should also serve as basic information some people may require to know for enterprising in the green sand casting business or relevant positive research purposes.

\section{ACKNOWLEDGEMENT}

We sincerely thank all workers in green sand casting of aluminum pots at Panteka Tudunwada in Kaduna metropolis, in Nigeria for their cooperation in giving us all information we needed know about their business. We also thank them for assisting us with their facilities to cast the pot and for working alongside with us at every process stage of casting the pot.

\section{REFERENCES}

[1]. Guma T.N., and Durami Jahleel, A. (2019). Assessment of Alkaline Food Environment Corrosion with some Menus at a Cadet Mess on the Tensile Strength of Aluminum 6063 Alloy. International Journal for Research in Applied Science \& Engineering Technology (IJRASET), Volume 7, Issue 1, January.

[2]. Guma, T. N (2010). Effect of 'Illo' Clay and Corn Flour Additives on the Foundry Properties of Kaduna River Sand in Nigeria. Journal of Chemical,
Mechanical and Engineering Practice, Volume 1 Numbers 2 \& 3, December.

[3]. Guma, T. N. (2012). Characteristic Foundry Properties of Kaduna River Sand. Research Inventy International Journal of Engineering and Science, Vol. 1, Issue 11, December, pp. 03-08.

[4]. Ogboi Lilian Uche (2018). Sand Casting Design, Production and Testing of a 30-Litre Capacity Aluminium Pot Using Locally Available Materials in Kaduna Metropolis. A Research Project Submitted to the Department of Mechanical Engineering, Faculty of Engineering, Nigerian Defence Academy, Kaduna, in Partial Fulfillment of the Requirement for the Award of Postgraduate Diploma in Mechanical Engineering (PGDME), Nigerian Defence Academy, Kaduna, Nigeria.

[5]. Guma. T.N. and Ogboi Uche Lilian (2019). Sand Mould Design for Casting an Aluminum Pot-A Basic Procedure of Supplementing Artisanal Practice. European Journal of Engineering Research and Science, 4 (4), April, pp. 24-30.

[6]. Pandey Lal Narayan (2015). Sand Casting-A Basic Review. International Journal of Innovative Research in Technology (IJIRT), Volume 2 Issue 7, December, pp. 477-483.

[7]. Shuaib-Babata Y. L., Yaru S. S., Abdulkareem S., Ajayi S., Busari Y. O., Ajao K. S., Ibrahim H. K., Ambali I. O. \& Mohammed G. A (2017). Suitability of some Selected Ado-Ekiti (Nigeria) Natural Moulding Sands' Properties for Sand Casting. Covenant Journal of Engineering Technology (CJET), Vol.1 No. 2, Dec., pp. 53-64.

[8]. Suraiya Jabeen, Bisma Ali, Moazzam Ali Khan, Muhammad Bilal Khan, Syed Adnan Hasan (2016). Aluminum Intoxication through Leaching in Food Preparation. Alexandria Science Exchange Journal, Vol 37, No. 4 Octobr- December 2016, pp. 618-626.

[9]. Salas Benjamín Valdez, Wiener Michael Schorr, Stoytcheva Margarita, Zlatev Roumen, and Beltran Monica Carrillo (2012). Corrosion in the Food Industry and its Control, In: Food Industrial Processes - Methods and Equipment, Edited by: Benjamin Valdez, InTech Publication, February, pp. 262-371.

[10]. Technical Document Guidelines on Metals and Alloys used as Food Contact Materials (2002). Council of Europe's Policy Statements Concerning Materials and Articles intended to Come into Contact with Foodstuffs Policy Statement Concerning Metals and Alloys-13 02. 


\section{International Journal of Engineering Applied Sciences and Technology, 2019 \\ Vol. 4, Issue 4, ISSN No. 2455-2143, Pages 169-178 \\ Published Online August 2019 in IJEAST (http://www.ijeast.com)}

[11]. Alteams-Innovative Partners in Aluminum Casting. http://www.alteams.com/about.as/contact-us/

Extracted 12/04/2018.

[12]. Sumaiya Shahria, Md. Tariquzzaman, Md. Habibur Rahman, Md. Al Amin, Md. Abdur Rahman (2017). Optimization of Molding Sand Composition for Casting Al Alloy. International Journal of Mechanical Engineering and Applications; 5(3): 155-161.

[13]. Datau S. G, Oji J. \& Ejilah I.R Datau N (2012). The Effect of Sand Casting Process Parameters on Mechanical Properties of Aluminum Alloy Casting. International Journal of Metallurgical \& Materials Science and Engineering (IJMMSE), Vol. 2, Issue 3 September, pp. 32-41.

[14]. American Society of Metals (ASM) International, Materials Park Russell, United States.

[15]. Foods Standard Agency. Guidance on Legal Compliance and Best Practice for Business, Documentation, Materials, and Articles in Contact with Food, September 2008.

[16]. Anilchandra A.R., Lars Arnberg 1, Franco Bonollo, Elena Fiorese, and Giulio Timelli (2017). Evaluating the Tensile Properties of Aluminum Foundry Alloys through Reference Castings-A Review, Materials, 10, 1011.

[17]. Ayoola Wasiu Ajibola, Adeosun Samson Oluropo, Sanni Olujide Samuel, i Oyetunji Akinlab (2012). .Effect Of Casting Mould on Mechanical Properties of
6063 Aluminum Alloy. Journal of Engineering Science and Technology, School of Engineering, Taylor's University Vol. 7, No. 1, pp. 89 - 96.

[18]. Qasim ZS, Jabbar MA, Hassan JJ (2017). Enhancement the Mechanical Properties of Aluminum Casting Alloys (A356) by Adding Nanorods Structures from Zinc Oxide. Journal of Material Science \& Eng, 6(2), pp.1-5

[19]. Joseph T. Adebayo Stephen, Adeyinka, and Adeyemi Gbenga J. (2018). Influence of Solidification Rates and Stress-Relief Annealing on the Mechanical Properties of Cast 6063 Aluminum Alloy. European Journal of Engineering Research and Science (EJERS) Vol.3, No. 5 May, pp. 71-76.

[20]. Bhargavi Rebbaa, Ramanaiah, N. (2014). Evaluation of Mechanical Properties of Aluminium Alloy (Al-2024) Reinforced with Molybdenum Disulphide $\left(\mathrm{MOS}_{2}\right)$ Metal Matrix Composites. 3rd International Conference on Materials Processing and Characterization (ICMPC), pp.1161-1169.

[21]. Aluminum Standards and Data 2006 Metric SI. Aluminum Association Inc.

[22]. ASM Handbook (2000), Volume 2: Properties and Selection: Nonferrous Alloys and Special-Purpose Materials. ASM Handbook Committee, pp. 102.

[23]. Shivkumar, Satya S., Wang, S., Keller, C. (1994). Impact Properties of A356-T6 Alloys. Journal of Materials Engineering and Performance, 3(1), pp. 8390. 